\title{
Mobilizing Resources for Marine Turtle Conservation in Asia A Cross-country Perspective ${ }^{1}$
}

Orapan Nabangchang.

Senior Economist of the Economy and Environment Program for Southeast Asia (EEPSEA) and a Faculty Member of the School of Economics, Sukhothai Thammatirat Open University in Thailand Jin Jianjun.

Associate Professor for College of Resources Science and Technology Beijing Normal University, China.

Anabeth Indab.

Environmental Economics Researcher for Resources at the Environment and Economics Center for Studies (REECS), the Philippines.

Truong Dang Thuy.

Researcher for Resources at the University of Economics HCMC, Vietnam.

Dieldre Harder.

Research Consultant, Resources at the Environment and Economics Center for Studies (REECS), The Philippines.

Rodelio F. Subade.

Director of the Institute for Fisheries Policy and Development Studies College of Fisheries and Ocean Sciences, and Associate Professor in Economics, Division of Social Sciences College of Arts and Sciences, both at the University of the Philippines,

\begin{abstract}
This article reports the results of a comparative study conducted in China, the Philippines, Thailand and Vietnam to assess households' willingness to pay for marine turtle conservation and the potential to mobilize funds. Results suggest that many people place a low priority on marine turtle conservation compared to other public policy issues. The referendum to impose a mandatory surcharge on residential electricity bills would only pass for the lowest surcharge of $0.02 \mathrm{USD} / \mathrm{month}$. If the poor were to be exempted, this modest surcharge would only generate a sum of 1.52 million USD per year which is under $8 \%$ of the total global expenses for marine turtles conservation.

Nevertheless, there is some potential for voluntary contributions. Based on the percentages of respondents who would voluntarily pay $1 \mathrm{USD} / \mathrm{month}$, the potential revenue could reach 50 million USD/year. Mobilizing these also presents problems. The voluntary payment explored, asking people to 'check off' for marine turtle conservation program on monthly electricity bills might work once, but unlikely to be repeatable for other endangered species and environmental causes. The traditional prescription of 'raising awareness' is unlikely to yield results as urban Asians are already well informed about the existence and plight of marine turtles. Efforts to develop conservation financing mechanisms should therefore be directed in a different and more difficult direction to improve the trustworthiness of government tax collection and expenditure systems. Charities could explore potential for voluntary contributions focusing on the relatively small segment willing to voluntarily contribute and developing cost-effective ways of collecting payments. Finally, until Asia develops higher per capita incomes and trustworthy payment vehicles, the international community will need to play an important role in financing conservation in the region.
\end{abstract}

\footnotetext{
${ }^{1}$ This article has been expanded from an earlier version under the same title published in the ASEAN Economic Bulletin. Vol. 25 No. 1 April 2008.
} 


\section{Introduction}

Marine turtles are important, not only for their economic and intrinsic value, but because the presence of an adequate population of marine turtles is often an indicator of healthy marine ecosystem (Perrine 2003). Of the seven species of marine turtles, four are classified by the International Union for the Conservation of Nature and Natural Resources (IUCN) as critically endangered, while two are in the next highest risk category (IUCN 2002). The marine turtles' status in Asia is of interest for two reasons. First, human activity in the region presents a wide variety of threats, including excessive and illegal harvesting for meat, shells, skin and eggs; habitat loss from development of beaches; destructive fishing methods such as dynamite fishing and use of drift nets; and pollution from shipping and tourism. Many of these threats are increasing rapidly with economic growth (IUCN 2002; Safina 2006). Second, marine turtles are a migratory species; their habitat is shared among a large number of countries such as China, the Philippines, Cambodia, Thailand, Malaysia, Vietnam and Indonesia. Coordinated policies to conserve marine turtles are thus more likely to be effective than those pursued by countries on their own. There is evidence of willingness of countries in East and Southeast Asia to collaborate but so far the measures taken have not been adequate to the challenge. ${ }^{1}$

This paper reports the results of a comparative research project carried out in China, Thailand, the Philippines and Vietnam. It explored the prospects for increased regional or national efforts to conserve marine turtles in Asia; whether Asians value turtles more for their use as food, shells, etc., than for non-use values; whether Asians are aware of marine turtles and their plight; and whether there is sufficient local willingness to pay to support larger conservation efforts. Using a common survey instrument, we applied the contingent valuation method (CVM) to assess the willingness of local populations to pay for the conservation of marine turtles. We estimated local willingness to pay and explored how a variety of payment vehicles affected people's decisions to support national and regional conservation plans. The survey instrument included an extensive set of attitudinal questions that allowed us to assess the relationship between respondents' attitudes, socioeconomic characteristics, and willingness to pay. The surveys were administered by dropping off questionnaires at people's residences, using similar procedures and protocols in each study country. Altogether 3,680 respondents participated in the survey; these were randomly selected spreading across all administrative districts in Beijing, Ho Chi Minh City, Hanoi, Bangkok and Davao City. The most populous of these cities is Beijing with over 15 million people; the smallest is Davao City in the Philippines, with about 1 million. Average annual per capita income ranges from US\$540 for Ho Chi Minh City/ Hanoi to US\$2,490 for Bangkok. There are also variations in culture and familiarity with the uses of marine turtles.

\section{Attitudes towards Environment, Wildlife and Marine Turtles}

We asked respondents to rank ten public policy issues: economic problems, poverty, education, health, crime/violence/inequality, government/ good governance, infrastructure, environment, terrorism, and relations with other countries. The survey revealed that people in all four countries accord relatively low priority to environmental protection. Only in Beijing does it appear among people's top three 
concerns. (See Table 1.) While environmental concerns do not feature as priority concerns, over 70 per cent of the respondents in all four countries agree that environmental problems are not properly taken care of.

Table 1: Social and Economic Priorities

\begin{tabular}{|c|c|c|c|c|}
\hline Rank & $\begin{array}{c}\text { Beijing } \\
\mathrm{N}=600\end{array}$ & $\begin{array}{c}\text { Davao City } \\
\mathrm{N}=847\end{array}$ & $\begin{array}{c}\text { Bangkok } \\
\mathrm{N}=789\end{array}$ & $\begin{array}{c}\text { Ho Chi Minh } \\
\text { City/Hanoi } \\
\mathrm{N}=1,444\end{array}$ \\
\hline 1 & $\begin{array}{c}\text { Economic } \\
\text { problems }\end{array}$ & $\begin{array}{c}\text { Economic } \\
\text { problems }\end{array}$ & $\begin{array}{c}\text { Economic } \\
\text { problems }\end{array}$ & $\begin{array}{c}\text { Economic } \\
\text { problems }\end{array}$ \\
\hline 2 & $\begin{array}{c}\text { Good } \\
\text { Governance }\end{array}$ & Poverty & Poverty & $\begin{array}{c}\text { Good } \\
\text { Governance }\end{array}$ \\
\hline 3 & Environment & $\begin{array}{c}\text { Good } \\
\text { Governance }\end{array}$ & $\begin{array}{c}\text { Good } \\
\text { Governance }\end{array}$ & Education \\
\hline
\end{tabular}

Note $\mathrm{N}=$ the total number of respondents surveyed.

Among environmental issues, we assessed how strongly people feel about the protection of wildlife. Respondents were asked to rank nine environmental issues: air pollution, water pollution, solid waste, loss of endangered species, deforestation, traffic congestion, soil erosion, global warming, and destruction of coral reefs. In none of the cities did wildlife conservation appear in the top three environmental concerns. (See Table 2.) Among the top three, there are few surprises. It appears that people are primarily concerned with environmental problems that affect their daily lives. Davao City was the only city where a non-urban issue (deforestation) ranked first, probably because it is located close to natural forests and has faced increasing incidences of flooding.

Studies have highlighted that conservation efforts for less known species have less public appeal than species that are more charismatic, cute or familiar (Tisdell and Wilson 2006). If this is the case, marine turtles may have fairly strong appeal.

Table 2: Environmental Priorities

\begin{tabular}{|c|c|c|c|c|}
\hline Ranking & $\begin{array}{c}\text { Beijing } \\
\mathrm{N}=600\end{array}$ & $\begin{array}{c}\text { Davao City } \\
\mathrm{N}=847\end{array}$ & $\begin{array}{c}\text { Bangkok } \\
\mathrm{N}=789\end{array}$ & $\begin{array}{c}\text { Ho Chi Minh } \\
\text { City/Hanoi } \\
\mathrm{N}=1,444\end{array}$ \\
\hline 1 & Air pollution & Deforestation & $\begin{array}{c}\text { Traffic } \\
\text { congestion }\end{array}$ & Air pollution \\
\hline 2 & Water pollution & Solid waste & Deforestation & Water pollution \\
\hline 3 & $\begin{array}{c}\text { Traffic } \\
\text { congestion }\end{array}$ & Air pollution & Air pollution & Deforestation \\
\hline
\end{tabular}

Note $\mathrm{N}=$ the total number of respondents surveyed.

First, as Table 3 reveals, the marine turtle is not an obscure species. Asians are familiar with them, although they may not have seen live turtles, or consumed their meat or eggs. These are, after all, urban populations with access to television, and as our survey results suggest, this may be more important source of information about environmental issues than formal education. Second, respondents in the five cities surveyed showed common preferences for marine turtles. 
Table 3: Familiarity and knowledge about marine turtles

Unit: \% of total respondents

\begin{tabular}{|l|c|c|c|c|}
\hline & $\begin{array}{c}\text { Beijing } \\
\mathrm{N}=600\end{array}$ & $\begin{array}{c}\text { Davao } \\
\text { City } \\
\mathrm{N}=847\end{array}$ & $\begin{array}{c}\text { Bangkok } \\
\mathrm{N}=789\end{array}$ & $\begin{array}{c}\text { Ho Chi } \\
\text { Minh } \\
\text { City/Hanoi } \\
\mathrm{N}=1,444\end{array}$ \\
\hline Seen a live Marine Turtle? & $53 \%$ & $67 \%$ & $57 \%$ & $24 \%$ \\
\hline Have eaten marine turtle eggs or meat? & $3 \%$ & $9 \%$ & $7 \%$ & $2 \%$ \\
\hline $\begin{array}{l}\text { Have purchased or owned a product made } \\
\text { from the shell of a marine turtle? }\end{array}$ & $6 \%$ & $4 \%$ & $10 \%$ & $5 \%$ \\
\hline $\begin{array}{l}\text { Watch Discovery Channel, or National } \\
\text { Geographic or any television show or video } \\
\text { document about marine turtles or other } \\
\text { animals? }\end{array}$ & $81 \%$ & $79 \%$ & $98 \%$ & $78 \%$ \\
\hline $\begin{array}{l}\text { Know that marine turtles have cultural value } \\
\text { in some societies in Indonesia, Thailand, } \\
\text { China and Malaysia (temple ceremonies, } \\
\text { 'release of life' ritual, etc }\end{array}$ & $44 \%$ & $27 \%$ & $51 \%$ & $45 \%$ \\
\hline Marine turtles lay their eggs on land. 1/ & $80 \%$ & $77 \%$ & $85 \%$ & $84 \%$ \\
\hline
\end{tabular}

Note: 1 / Figures shown are percentage who gave correct answer that this statement was 'TRUE'

The survey asked respondents to prioritize six endangered species for priority of allocation of conservation resources; the species were marine turtles, dugongs, whalesharks, Philippine eagles, black-faced spoonbills and Javan rhinos. In all cases, marine turtles were ranked either first or second (Table 4). ${ }^{2}$ However, an individual may be concerned about animals in general or specific species, without taking action to prevent their extinction. He or she may assume that someone else will or should solve the problem. There is some evidence of this in the survey results. When 57 per cent to 65 per cent of respondents strongly agree that "it is everyone's duty to ensure that plants and animals as we know them today will exist for mankind in the future", we might conclude that most people have "pro-environmental" attitudes. When making personal trade-offs, however, there is a notable drop in supporting opinions. Only 4 per cent of the respondents in Davao strongly agreed that "governments should raise taxes for more endangered species protection". The percentage of "strongly agree" in the other cities was similarly low.

Table 4: Ranking for priority in resource allocation

\begin{tabular}{|c|c|c|c|c|}
\hline Rank & $\begin{array}{c}\text { Beijing } \\
\mathrm{N}=600\end{array}$ & $\begin{array}{c}\text { Davao City } \\
\mathrm{N}=847\end{array}$ & $\begin{array}{c}\text { Bangkok } \\
\mathrm{N}=789\end{array}$ & $\begin{array}{c}\text { Ho Chi Minh } \\
\text { City/Hanoi } \\
\mathrm{N}=1,444\end{array}$ \\
\hline 1 & Marine turtles & Marine turtles & Dugongs & White rhino \\
\hline 2 & Dugongs & $\begin{array}{c}\text { Philippine } \\
\text { eagles }\end{array}$ & Marine turtle & Marine turtles \\
\hline 3 & Whalesharks & Dugongs & Whaleshark & Dugongs \\
\hline
\end{tabular}

Note $\mathrm{N}=$ the total number of respondents surveyed. 


\section{The Potential for Private Contributions for Marine Turtle Conservation}

In order to assess willingness to pay (WTP), we constructed a hypothetical marine turtle conservation programme. We provided information about the importance of marine turtles to coastal and oceans ecosystems; described the threats and risks of extinction; and introduced a hypothetical marine conservation programme. We then asked respondents whether they would be willing to contribute to the programme by paying a monthly surcharge on their electricity bills for a period of five years.

We adopted this payment vehicle because focus group discussions conducted prior to our pre-tests and surveys revealed a distinct lack of enthusiasm for taxes as a payment vehicle. Among the explanations offered was that people believe they are already too highly taxed or do not believe the taxes will be effectively collected or used. Distaste for taxes as a payment vehicle is a finding of many contingent valuation studies, not only in East and Southeast Asia (Bateman et al. 2002; Champ, Boyle, and Browne 2003).

We therefore tried to assess people's willingness to pay for conservation through an alternative payment vehicle: a surcharge attached to each household's electricity bills. We looked at two variants: a mandatory charge and a voluntary charge. In the mandatory payment scheme, respondents were presented with a hypothetical referendum and asked to vote for or against a specified monthly surcharge on all household electricity bills for a period of five years. Respondents were told to assume that if more than 50 per cent voted to pass the referendum, the surcharge would be imposed on all households regardless of how they voted. In the voluntary payment scheme, respondents were asked whether they would voluntarily make a private contribution, with no assurance that anyone else would pay it.

We asked separate groups of respondents their willingness to pay for one of three marine turtle conservation packages: (i) a region-wide programme financed through a mandatory charge; (ii) a region-wide programme financed through voluntary contributions, and (iii) a national programme financed through a mandatory charge. The region-wide programmes would involve the collaboration of many countries, including the four surveyed. In principle, the likelihood of success of the regional programme would be greater than that of a single-country programme, given the species' transboundary habitat. For the region-wide programme to be financed by the mandatory charge system, over 50 per cent of respondents in each of the four countries would have to vote in favour for the programme to be implemented. In other words, respondents were told to assume that if the referendum did not pass in one of the countries, the international effort would not go ahead.

Altogether 1,249 respondents were randomly selected to respond to the region-wide programme with mandatory payment; 1,220 to the region-wide programme with voluntary payment; and 1,211 to the single-country programme with mandatory payment. Each set of respondents was divided into five groups, each of which was asked to give a yes-or-no response to one of five amounts, or bid levels, ranging from US\$0.02 to US\$7.5 per month. ${ }^{3}$ 
Our findings show that, while respondents are familiar with marine turtles and believe them to be important, they are not concerned to a degree that would lead them to make personal trade-offs by making private contribution. Table 5 shows that only the lowest surcharge (US\$0.02) would pass a referendum in all four countries. For Davao City, Bangkok, Hanoi, and Ho Chi Minh City, the referendum would also pass at the next lowest bid prices which were US\$0.1, US\$0.25, and US\$0.5 respectively. The second lowest bid for Beijing was US\$0.5 and only 48 per cent of the respondents voted to pass the referendum. At bids of US\$1 and above, the referendum would not pass in any of the countries.

Table 5: The number of respondents saying 'Yes' to each bid under the Regional Mandatory Program

\begin{tabular}{|c|c|c|c|c|}
\hline $\begin{array}{c}\text { Bid } \\
\text { (US\$/month/hh) }\end{array}$ & Beijng & Davao & Bangkok & HCMC\&Hanoi \\
\hline (.02USD) & $\begin{array}{c}30 \\
(75) \\
\end{array}$ & $\begin{array}{c}32 \\
(56) \\
\end{array}$ & $\begin{array}{c}39 \\
(67) \\
\end{array}$ & $\begin{array}{c}78 \\
(81) \\
\end{array}$ \\
\hline 0.1 & & $\begin{array}{c}30 \\
(56)\end{array}$ & & \\
\hline 0.25 & & & $\begin{array}{c}37 \\
(66)\end{array}$ & \\
\hline 0.5 & $\begin{array}{c}19 \\
(48)\end{array}$ & & & $\begin{array}{c}68 \\
(69)\end{array}$ \\
\hline (1USD) & $\begin{array}{c}16 \\
(40)\end{array}$ & $\begin{array}{c}17 \\
(28)\end{array}$ & $\begin{array}{c}20 \\
(36)\end{array}$ & $\begin{array}{c}44 \\
(44)\end{array}$ \\
\hline 2USD & & $\begin{array}{c}17 \\
(31)\end{array}$ & & \\
\hline 2.5 USD & & & $\begin{array}{c}18 \\
(33)\end{array}$ & \\
\hline (5 USD) & $\begin{array}{c}8 \\
(20)\end{array}$ & $\begin{array}{c}11 \\
(20)\end{array}$ & $\begin{array}{c}7 \\
(13)\end{array}$ & $\begin{array}{c}17 \\
(17)\end{array}$ \\
\hline 7.5USD & $\begin{array}{c}2 \\
(5)\end{array}$ & & & $\begin{array}{c}20 \\
(21)\end{array}$ \\
\hline
\end{tabular}

Notes:

1. The shaded rows are the three common bid values used in all four countries. However, Bids 2 and 4 are set differently.

2. Figures in parentheses are percentages of "Yes" responses from the number of responses in the split sample.

For each city surveyed, we found that respondents were willing to make only small payments. In the Regional Mandatory Conservation Programme, the mean WTPs for Davao City were US\$0.17/household/months and for Ho Chi Minh City and Hanoi at US\$0.83 per household per month. ${ }^{4}$ MWTP for the two higher income cities were US\$1.16 and US\$1.41 per household per month for Beijing and Bangkok respectively. These values are comparable to the WTP values for other species from studies in Asia. ${ }^{5}$ 
The pattern of response to the Regional Voluntary Programme in Table 6 indicates that, similar to the Mandatory Programme, the percentages of the respondents who would be willing to contribute decreases significantly as the bids get higher.

We also found no significant difference in the level of support for variations in the conservation programs we offered. With the exception of Ho Chi Minh City/Hanoi, where results suggest that respondents would be willing to pay significantly higher for the mandatory programme, respondents in Beijing, Davao City and Bangkok appear to be indifferent. Nor were there significant differences in the MWTP between international and national scale of efforts. Again, Ho Chi Minh City/Hanoi is the exception with where the MWTP for the conservation efforts is higher for the international scale conservation efforts. ${ }^{6}$

One encouraging finding is that a significant percentage of respondents would voluntarily pay, regardless of whether or not other people paid. Moreover, while the estimated MWTP values presented earlier are indeed low and lower than WTP values in developed countries for endangered species, given the large income difference between the United States and the four countries surveyed, this difference in mean WTP was not unexpected. For example, the average U.S. citizen was willing to pay US\$7.5/hh/month (Loomis, Gonzalez-Caban, and Gregory 1996) for the spotted owl and US\$2.77/hh/month for the gray-blue whale (Bulte and Van Kooten 1999). But Gross National Income per capita for a U.S, citizen in 2005 was nearly sixteen times higher than that of Thailand. ${ }^{7}$

Thus, even if those who agreed to make voluntary contributions are not in the majority, and are willing to make only small contributions, they do constitute a potential source of finance for conservation. 
Table 6: The number of respondents saying 'Yes' to each bid under the Regional Voluntary Program

\begin{tabular}{|c|c|c|c|c|}
\hline $\begin{array}{c}\text { Bid } \\
\text { (US\$/month/hh) }\end{array}$ & Beijng & Davao & Bangkok & HCMC\&Hanoi \\
\hline (.02USD) & $\begin{array}{c}29 \\
(73)\end{array}$ & $\begin{array}{c}36 \\
(60) \\
\end{array}$ & $\begin{array}{c}42 \\
(81) \\
\end{array}$ & $\begin{array}{c}60 \\
(65) \\
\end{array}$ \\
\hline 0.1 & & $\begin{array}{c}38 \\
(69)\end{array}$ & & \\
\hline 0.25 & & & $\begin{array}{c}31 \\
(61)\end{array}$ & \\
\hline 0.5 & $\begin{array}{c}23 \\
(58)\end{array}$ & & & $\begin{array}{c}60 \\
(61)\end{array}$ \\
\hline (1USD) & $\begin{array}{c}20 \\
(50)\end{array}$ & $\begin{array}{c}18 \\
(33)\end{array}$ & $\begin{array}{c}19 \\
(35)\end{array}$ & $\begin{array}{c}27 \\
(29)\end{array}$ \\
\hline 2 & & $\begin{array}{c}17 \\
(30)\end{array}$ & & \\
\hline 2.5 & & & $\begin{array}{c}20 \\
(38)\end{array}$ & \\
\hline (5 USD) & $\begin{array}{c}7 \\
(18)\end{array}$ & $\begin{array}{c}11 \\
(19)\end{array}$ & $\begin{array}{c}9 \\
(17)\end{array}$ & $\begin{array}{c}20 \\
(20)\end{array}$ \\
\hline 7.5USD & $\begin{array}{c}3 \\
(8)\end{array}$ & & & $\begin{array}{c}11 \\
(12)\end{array}$ \\
\hline
\end{tabular}

Note:

1/ The shaded rows are the three common bid values used in all four countries. However, Bids 2 and 4 are set differently.

2/ Figures in parenthesis are percentages of 'Yes' responses from the number of respondents in the split sample

There were observed commonalities in the reasons as to why respondents decided to contribute money for the establishment of a marine turtle conservation fund. There appeared to be a consensus that the most important reason was because respondents thought marine turtle was an important animal and should be protected. From Table 7, the Vietnamese respondents placed more importance to the 'collaborative efforts' among countries whereas Thai respondents saw the merit of this initiative for marine turtles conservation as paving the way for other endangered species conservation efforts. This was indeed also the sentiment of those in Beijing although this respondent group also attached importance to country collaborative efforts. 
Table 7: Reasons why respondents decided to contribute money for the establishment of a marine turtle conservation fund

$\%$ of respondents who said 'Yes' to the WTP question

\begin{tabular}{|l|c|c|c|c|}
\hline \multicolumn{1}{|c|}{ Reasons } & Beijing & $\begin{array}{c}\text { Davao } \\
\text { city }\end{array}$ & Bangkok & $\begin{array}{c}\text { HCM/H } \\
\text { anoi }\end{array}$ \\
\hline $\begin{array}{l}\text { The marine turtle is an important animal } \\
\text { and should be protected }\end{array}$ & 48 & 41 & 39 & 34 \\
\hline $\begin{array}{l}\text { I believe that marine turtles can only be } \\
\text { protected through the collaboration of } \\
\text { several countries }\end{array}$ & 19 & 6 & 10 & 29 \\
\hline $\begin{array}{l}\text { It is high time that the people in East } \\
\text { Asia do something concrete about } \\
\text { protecting the marine turtles since this is } \\
\text { the center of illegal trade in the world }\end{array}$ & 4 & 16 & 9 & 9 \\
\hline $\begin{array}{l}\text { This initiative can lead to more protection } \\
\text { efforts for other endangered species in } \\
\text { the region. }\end{array}$ & 22 & 15 & 21 & 9 \\
\hline
\end{tabular}

As to why respondents decided not to support the proposed marine turtle conservation fund, with the exception of Thailand, the most common response was that they could not afford the amount. Affordability was less of an issue for Bangkok respondents than their attitude towards the government as during the survey period in Bangkok, perceptions towards the government of the time tended to be on the negative side, hence the most common reason for deciding not to support marine conservation was because they thought it should be the responsibility of the government which after all, already had their tax revenue. (Table 8)

Table 8: Reasons why respondents voted 'against' the referendum.

$\%$ of respondents who said ' $N o$ ' to the WTP question

\begin{tabular}{|l|c|c|c|c|}
\hline \multicolumn{1}{|c|}{ Reasons } & Beijing & $\begin{array}{c}\text { Davao } \\
\text { city }\end{array}$ & Bangkok & $\begin{array}{c}\text { HCM/H } \\
\text { anoi }\end{array}$ \\
\hline I cannot afford that amount. & 39 & 36 & 13 & 27 \\
\hline $\begin{array}{l}\text { I do not trust the institutions that will } \\
\text { handle the money for this conservation } \\
\text { work. }\end{array}$ & 20 & 5 & 14 & 19 \\
\hline $\begin{array}{l}\text { I do not believe paying will solve the } \\
\text { problem. }\end{array}$ & 18 & 5 & 4 & 11 \\
\hline $\begin{array}{l}\text { It should be the government's } \\
\text { responsibility since it already has money } \\
\text { from my tax revenues. }\end{array}$ & 7 & 27 & 41 & 10 \\
\hline
\end{tabular}

\section{Factors Influencing Decision Making}

To analyse factors which influenced decision making, we pooled the data for all the three scenarios (Regional Mandatory, Regional Voluntary and National Mandatory). The variables included in the multivariate analysis and definitions are presented in Table 9. 
Table 9: Variables included in the multivariate analysis and definitions.

\begin{tabular}{|l|l|}
\hline Variable & Definition \\
\hline Bid & Bid used in WTP question (US\$) \\
\hline HHsize & Number of household members living together \\
\hline Age & Age of respondents \\
\hline Gender & $1=$ male, $0=$ female \\
\hline Education & Education of respondents (years of schooling) \\
\hline Income & Total household income (1000 US\$/month) \\
\hline Marriage & $1=$ married , $0=$ others \\
\hline Member & $* 1 *$ for environmental organization member, and $* 0 *$ otherwise \\
\hline Cn & $1=$ Beijing , 0 others \\
\hline $\mathrm{Ph}$ & $1=$ Davao , $0=$ others \\
\hline Th & $1=$ Bangkok , $0=$ others \\
\hline
\end{tabular}

Results in Table 10 conformed to a priori expectations where in all the models, the Bid variable was significant at 0.01 significance level and negative coefficient sign indicating the reduced probability of respondents answering 'Yes' to the WTP question as the Bid price increases. In the pooled sample education and income were also significant at 0.01 significance level both with positive coefficients indicating that as the higher the level of education and income, the higher the probability those respondents would vote in favour of the referendum. Whether or not respondents were already members of environmental organizations also increased the likelihood of 'Yes' responses and in the pooled sample, this variable was significant at 0.01 significance level.

Apart from Bid and Income which were statistically significant for all country models, the influence of other variables varied. Education for instance was significant only for China and Vietnam at 0.05 significance level. The Member variable was significant only for China and the Philippines. The size of the household and whether or not the respondent was married were significant only in the Vietnam model; both had negative coefficient signs suggesting that the larger the household size, the lower the probability that they will be willing to pay. This was what was consistent with expectations that larger families would have larger expenditures as would married people by comparison to respondents who were single. 
Table 10: The logit regression

\begin{tabular}{|c|c|c|c|c|c|c|c|c|c|c|}
\hline & \multicolumn{2}{|l|}{ China } & \multicolumn{2}{|c|}{ Philippines } & \multicolumn{2}{|l|}{ Thailand } & \multicolumn{2}{|c|}{ Viet Nam } & \multicolumn{2}{|l|}{ Pooled } \\
\hline & Coeff. & Std err & Coeff. & $\begin{array}{l}\text { Std } \\
\text { err }\end{array}$ & Coeff. & $\begin{array}{l}\text { Std } \\
\text { err }\end{array}$ & Coeff. & $\begin{array}{l}\text { Std } \\
\text { err }\end{array}$ & Coeff. & $\begin{array}{l}\text { Std } \\
\text { err }\end{array}$ \\
\hline Bid & $\begin{array}{c}-0.365 \\
* * *\end{array}$ & 0.046 & $\begin{array}{c}-0.422 \\
* * *\end{array}$ & 0.052 & $\begin{array}{c}-0.519 \\
* * *\end{array}$ & 0.061 & $\begin{array}{c}-0.503 \\
* * *\end{array}$ & 0.053 & $\begin{array}{c}-0.438 \\
* * *\end{array}$ & 0.026 \\
\hline Hhsize & 0.085 & 0.077 & -0.008 & 0.032 & 0.018 & 0.048 & $\begin{array}{c}-0.065 \\
* *\end{array}$ & 0.032 & -0.007 & 0.019 \\
\hline Age & 0.001 & 0.009 & -0.005 & 0.006 & 0.001 & 0.009 & 0.008 & 0.005 & -0.002 & 0.003 \\
\hline gender & 0.036 & 0.204 & 0.129 & 0.160 & -0.040 & 0.168 & 0.132 & 0.122 & 0.109 & 0.077 \\
\hline Education & $\begin{array}{c}0.070 \\
* *\end{array}$ & 0.032 & -0.013 & 0.028 & 0.038 & 0.028 & $\begin{array}{c}0.036 \\
* *\end{array}$ & 0.015 & $\begin{array}{c}0.034 \\
* * *\end{array}$ & 0.011 \\
\hline Income & $\begin{array}{c}0.001 \\
* * *\end{array}$ & 0.000 & $\begin{array}{c}0.002 \\
* * *\end{array}$ & 0.001 & $\begin{array}{c}0.0003 \\
*\end{array}$ & 0.000 & $\begin{array}{c}0.001 \\
* * *\end{array}$ & 0.000 & $\begin{array}{c}0.001 \\
* * *\end{array}$ & 0.000 \\
\hline Marriage & 0.385 & 0.315 & 0.044 & 0.199 & 0.203 & 0.187 & $\begin{array}{c}-0.408 \\
* * *\end{array}$ & 0.155 & -0.0002 & 0.087 \\
\hline Member & $\begin{array}{c}0.894 \\
* *\end{array}$ & 0.355 & $\begin{array}{c}0.808 \\
* * *\end{array}$ & 0.235 & 0.432 & 0.417 & 0.215 & 0.345 & $\begin{array}{c}0.658 \\
* * *\end{array}$ & 0.156 \\
\hline China & & & & & & & & & 0.049 & 0.136 \\
\hline Phil. & & & & & & & & & $\begin{array}{c}0.440 \\
* * *\end{array}$ & 0.102 \\
\hline Thai & & & & & & & & & -0.159 & 0.112 \\
\hline _cons & $\begin{array}{c}-2.077 \\
* * *\end{array}$ & 0.706 & -0.003 & 0.501 & $\begin{array}{c}-1.027 \\
*\end{array}$ & 0.615 & $\begin{array}{c}-0.713 \\
* *\end{array}$ & 0.309 & $\begin{array}{c}-0.821 \\
* * *\end{array}$ & 0.225 \\
\hline $\begin{array}{l}\text { Log- } \\
\text { likelihood }\end{array}$ & -302.2 & & -502.5 & & -433.6 & & -810.1 & & -2069.6 & \\
\hline Pseudo R2 & 0.17 & & 0.09 & & 0.12 & & 0.10 & & 0.10 & \\
\hline $\mathrm{N}$ & 598 & & 839 & & 789 & & 1430 & & 3656 & \\
\hline
\end{tabular}

\section{Summary and Conclusions}

Our study has shown that people in several cities in Southeast Asia are already exposed to abundant information, generally aware and well informed about marine turtles. They believe that conservation is important but at the moment, their priorities understandably lie in other public policy issues such as improving governance and reducing poverty. A mandatory surcharge on electricity bills to support marine turtle conservation would only pass at the lowest bid of US\$0.02 in all cities surveyed. Our results provide some support for the proposition that voluntary contributions could provide considerable sums for marine turtle conservation. The potential revenue, based on the percentages of respondents in the cities who would voluntarily pay US\$1 per month, would be around US\$50million per year.8 This is much less than what could be mobilized were the mandatory payment referenda passed in the four countries surveyed (US\$135 million). ${ }^{9}$ But it is more than the current global expenditures on marine turtle conservation of 162 conservation organizations combined, estimated at some US\$20 million per year (Treung and Drews 2004). Having said that, the harsh reality is that actually mobilizing these contributions would be difficult. The voluntary payment vehicle we explored was a "check-off" for a marine turtle conservation programme on a household's monthly electricity bill. While this might work once, it is not feasible to put check-off boxes on utility bills for every species or environmental cause. In the long run, these efforts must be financed 
primarily out of general government revenue or "user-pay" schemes like environmental service payments. An important implication of our findings is that the traditional prescription of "raising awareness" is unlikely to yield results: people in Asia are already well informed about the existence and plight of marine turtles. Efforts to develop conservation finance mechanisms should therefore be directed in a different and more difficult direction: improving the trustworthiness of government tax collection and expenditure systems. Conservation agencies might play a role in this by working with governments to set up trust funds in which public funds could be deposited with confidence. Charities could also explore the potential for voluntary contributions revealed by this study; their efforts should go primarily into identifying the relatively small segment of the population that is willing to contribute and to developing cost-effective ways of collecting payments. Eventually, as incomes rise and governance improves, Asia's ability to pay for conservation will increase. In the meantime, contributions from the international community will continue to be important in conserving what is, after all, a global resource.

\section{Acknowledgments}

We would like to thank the Economy and Environment Programme for Southeast Asia (EEPSEA) for providing the financial support to undertake this study. We thank Dr David Glover, Founding Director of EEPSEA and Dr Herminia Francisco, present Director of EEPSEA since January 2007, for their technical support, comments and opportunities for series of meetings which facilitated organization and coordination of cross-country efforts. We would also like to thank Dr Dale Whittington (University of North Carolina at Chapel Hill, USA), and Dr Wiktor (Vic) Adamowicz (University of Alberta, Canada) for their valuable suggestions and support which helped us carry through this study.

\section{NOTES}

1. An example is the Turtle Islands Heritage Protected Area (THIPA) which is a transboundary protected area initiated in 1997, and has been jointly implemented by the Philippines and Malaysia.

2. The survey was conducted by dropping off a questionnaire and information packet with each household and collecting it later. It is possible that some respondents read the entire survey instrument - including the willingness to pay question about turtle conservation - before filling out the attitudinal questions. If so, this may partially explain the high-ranking for marine turtles. But it does not explain the relatively low ranking for environmental issues and for wildlife conservation among environmental issues. So we have some confidence that the high priority accorded to marine turtles is not an artifact of the survey instrument.

3. For details of the methodology of this study, the parametrics and non-parametrics analysis, see Indab et al. (2006),]

4. The results are from parametric estimates assuming normal distribution.

5. MWTP (Mean Willingness to Pay) for the black-faced spoonbill in Macao was estimated at 9.51 MOP (US\$1.19)/household/month (Jinjuan 2006). MWTP for Philippines' whale sharks US\$0.5/household/month for whalesharks (Indab 2006) where as the estimated lump sum contribution to conservation measures for the Philippines eagle was US\$63/household (Harder 2006). Estimated MWTP for the Javan Rhino based on CVM study conducted in Vietnam was US\$0.21/household/month (Truong 2006).

6. We asked separate groups of respondents their WTP for a national and a (larger) international programme, partly with the intention of using this as a "scope" test to 
see if respondents were making rational choices. However, there is reason to believe that such "external" scope tests are unrealistic; valuation is an inherently comparative process (M. Hanemann, personal communication). For this reason, we do not believe that the apparent scope insensitivity of respondents invalidates our findings. See Jianjun Jin. et. al Valuing marine turtle conservation: A cross-country study in Asian cities. Ecological Economics. 69 (2010) 2020-2026

7. From World Bank's country statistics, GNI per capita for the United States in 2005 was US $\$ 43,740$.

8. For Beijing for example, the estimation is based on the assumption that 50 per cent of 5.12 million households in Beijing would pay (50 per cent being the percentage of respondents in our survey who agreed to voluntary contribution of US\$1 per month). Similar approach was used for Davao City and Bangkok. The voluntary contributions for the other cities were estimated using the percentages of respondents agreeing to voluntarily contribute US $\$ 1$ per month, that is, 33 per cent of the 0.23 million households in Davao City, 35 per cent of the 2.091 million households in Bangkok and 29 per cent of 2.75 million households in Ho Chi Minh City and Hanoi.

9. Estimated by using the MWTP for each city and the estimated number of households in each city.

\section{REFERENCES}

Bateman, Ian J., Richard T. Carson, Brett Day, Michael Hanemann, Nick Hanley, Tannis Hett, Michael Jones-Lee, Graham Loomes, Susana Mourato, Ece Özdemiroglu, David W. Pearce OBE, Robert Sugden and John Swanson. Economic Valuation with Stated Preference Techniques. UK: Edward Elgar Publishing, 2002.

Bulte, Erwin H. and G. Cornelius Van Kooten. "1998 Marginal Valuation of Charismatic Species: Implications for Conservation”. Environmental and Resources Economics 14 (1999): 119-30.

Champ, P.A., Boyle K.J., and Browne, T. C., eds. A Primer on Nonmarket Valuation. Doredrecht; Boston: Kluwer Academic Publishers, 2003.

Harder D. "Willingness to Pay for Conservation of Endangered Species in the Philippines: The Philippines Eagle”. EEPSEA Research Report, 2006.

Indab A. "Conservation Value of Endangered Species in the Philippines: A CVM Exercise". EEPSEA Research Report, 2006.

Indab A., Jin Jianjun, Truong Dang Thuy, Orapan Nabangchang, Dieldre Harder and Rodel Subade. "Valuing the

Marine Turtle Conservation Using the Contingent Valuation Method: A Cross-country Study in Asia, 2007”. Paper presented at the Third World Congress of Environmental and Natural Resource Economists, Kyoto, 3-7 July 2006.

International Union for the Conservation of Nature and Natural Resources (IUCN). 2002 Red List. <www.iucnredlist.org>.

Jinjuan J. "Economic Valuation of the Black-faced Spoonbill Conservation in Macao”. EEPSEA Research Report, 2006.

Jianjun Jin, Anabeth Indab, Orapan Nabangchang, Truong Dang Thuy, Dieldre Harder, Rodelio F. Subade. Valuing marine turtle conservation: A cross-country study in Asian cities. Ecological Economics. 69 (2010) 2020-2026

Loomis J. B., A. Gonzalez-Caban, R. Gregory. “A Contingent Valuation Study of the Value of Reducing Fire Hazards to Old Growth Forests in the Pacific Northwest".: USDA Forest Service Research Paper PSW-RP-229-Web, July 1996.

Perrine D. Sea Turtles of the World. Stillwater, Minnesota: Voyageur Press, 2003.

Safina, Carl. Voyage of the Turtle:In Pursuit of the Earth's Last Dinosaur. USA: Henry Holt and Company, 2006. 
Tisdell C. and C. Wilson. "Information, Wildlife Valuation, Conservation: Experiment". Contemporary Economic Policy 24, no.1 (January 2006): 144-59.

Troeng S. and C. Drews. "Money Talks: Economic Aspects of Marine Turtle Use and Conservation”. WWFInternational- Gland, Switzerland, $2004<$ www.panda.org>.

Truong Dang Thuy. "Willingness to Pay For Conservation of Endangered Species in Vietnam: Rhino”. EEPSEA 